Quest Journals

Journal of Research in Business and Management

Volume 4 Issue 12(2017) pp: 73-78

ISSN (Online) : 2347-3002

www.questjournals.org

Research Paper

\title{
Marketing mix: effects of service quality and consumer behavior on loyalty. The mediating role of customer satisfaction
}

\author{
Rego Devila', Sosiawan Ma'mun ${ }^{2}$, Ansar $^{3}$ \\ ${ }^{1,2)}$ Indonesian College of Teacher Training and Education (STKIP-PI), Makassar South Sulawesi \\ ${ }^{3)}$ Indonesian fighters University (UPRI), Makassar South Sulawesi
}

Received 18 Feb, 2017; Accepted 03 Mar, 2017 ( ) The author(s) 2017. Published with open access at www.questjournals.org

\begin{abstract}
The purpose of this study was to analyze the effect of the marketing mix, quality of service and consumer behavior towards customer satisfaction and loyalty cement. This research was conducted in South Sulawesi province with a population of 1,618 people and carried out with the formula slovin 5\%, the total sample of 323 respondents. The study's hypotheses were tested using a model of Structural Equation Model (AMOS ver. 18). The study found that direct marketing mix positive and significant impact on customer satisfaction cement; service quality and significant positive effect on customer satisfaction cement; consumer behavior and significant positive effect on customer satisfaction. Marketing mix has a positive and significant impact on customer loyalty cement; service quality and no significant positive effect on customer loyalty cement; consumer behavior and no significant positive effect on customer loyalty cement. Satisfaction has a positive and significant effect on customer loyalty cement. Marketing mix has a negative and significant effect on loyalty through customer satisfaction. Service qualities have a negative and insignificant effect on loyalty through customer satisfaction. Consumer behaviors have a negative and insignificant effect on loyalty through customer satisfaction.
\end{abstract}

Keywords - consumer behavior, customer loyalty, marketing mix, satisfaction, service quality

\section{INTRODUCTION}

The development and progress of a region such as a province has always been characterized by the rapid development of infrastructure such as the construction of concrete roads, multi-storey buildings (hotels, shopping centers and office buildings), residential and public facilities owned by a province. The constructions activities cannot be separated from the use of materials one of which is cement with different types of cement brands are available in one province. As in South Sulawesi Province, there are four dominant species marketed, among others Tonasa, Bosowa, Indocement and Holcim cement.

The cement industry is a strategic industry that developed rapidly in the country. In line with the improvement in economic growth and welfare of the people, the potential need for cement continues to increase between 8-10 percent. A huge market potential and levels of increasingly sharp competition demands the precision management company to develop the concept of the marketing mix, quality of service, consumer behavior, customer satisfaction and loyalty (Soetjipto, 2013: 1). The fifth case mentioned above becomes the newest thing as a novelty that needs to be examined from the aspect of the phenomenon, reality, data and gaps in this regard to observe and be observed in relation to the implementation of the management helm (top leader) played in determining the direction the company's policy continues to grow and compete with competitors operating in the same field. The company faces competition certainly finds various problems and obstacles that must be faced and resolved.

Problems that became a phenomenon related to the marketing mix, quality of service and consumer behavior that directly or indirectly affect customer satisfaction and loyalty. For distributors and sub-distributors of cement in South Sulawesi Province in addressing this to resolve conflict issues relating to corporate synergy as a distribution channel to improve distribution of cement to the entire region of South Sulawesi, to provide reinforcement for implementing the marketing mix, improve service quality and attention consumer behavior to achieve customer satisfaction and loyalty in the use of cement products.

The problem faced by the cement company in South Sulawesi seen from the declining level of customer loyalty to each brand of cement due to customer dissatisfaction over the cement used for the application of the marketing mix, the quality of services provided and the lack of attention on consumer behavior into problems

*Corresponding Author: Rego Devila

Indonesian College of Teacher Training and Education (STKIP-PI), Makassar South Sulawesi

73 | Page 
frequently complained the parties involved in the marketing of cement. The phenomenon that shows the level of customer loyalty decline, this cannot be separated from the reality that is found on the ground that the indication of customer loyalty decline due to reduced levels of repeat purchases(repeat purchase)of distributors as customers, less recommend to sub-distributors to continue to purchase and often leave negative responses cement products are bought, so that there is the tendency for less loyal distributors make purchases that lead to decreased customer loyalty.

Understanding customer loyalty is low, and then it needs to be improved by applying the theory of assuming fidelity of Norman (2005: 87) states that customer loyalty is an attitude that please and always use your products and services over and over and do not use other services. On this basis, the management of marketing in this case the company should be able to consider the orientation of customer loyalty. The next fact is found in general the distributors as customers often complain of cement products bought from the cement company. Complaints and dissatisfaction is often not getting the channel or container to listen to the voice of the customer. The distributors and sub-distributors are also aware that the lack of awareness of the company in the management system of complaints and suggestions cause cannot determine the level of customer satisfaction, but it rarely did a survey on customer satisfaction in fact, the company has limited to ghost shopping for the detection sensitivity of the products used customer. And the management company also rarely makes contact with old customers or distributors as a form of attention. As a result of the lack of consideration and attention to the many distributors as customers are less satisfied.

Upon consideration of customer dissatisfaction, then the cement company should consider the theory of satisfaction assessment (Kotler, 2013: 17) that customer satisfaction can be known through the system of complaints and suggestions, satisfaction surveys, activities ghost shopping Contact and old customers. This into consideration to assess customer satisfaction with the products and services offered by the company. The following data is showing always been a problem in the last five years in marketing activities of cement, showing a decrease in the level of purchasing cement from the distributor caused many stocks cement provided have not been channeled to the developer, projects and communities in need of cement which makes the satisfaction and loyalty of distributors as customers also declined. More specifically data from Cement Distributors Association of South Sulawesi province:

Table 1 Percentage Rate Cement Purchase of Distributors in South Sulawesi

\begin{tabular}{|c|c|c|c|c|c|c|}
\hline \multirow{2}{*}{ Year } & \multicolumn{4}{|c|}{ Percentage of Purchase level (\%) } & \multirow{2}{*}{ Satisfaction } & \multirow{2}{*}{ Loyalty } \\
\hline & Tonasa & Bosowa & Indocement & Holcim & & \\
\hline 2011 & 60.7 & 74.6 & 55.8 & 54.9 & 65.8 & 60.8 \\
\hline 2012 & 72.9 & 68.4 & 52.7 & 53.7 & 63.4 & 59.7 \\
\hline 2013 & 65.7 & 63.7 & 61.2 & 52.8 & 68.5 & 57.3 \\
\hline 2014 & 63.8 & 67.2 & 58.4 & 55.4 & 64.7 & 56.8 \\
\hline 2015 & 62.9 & 63.8 & 55.6 & 53.8 & 52.9 & 55.4 \\
\hline
\end{tabular}

Source: Association of Cement Distributors in South Sulawesi Province (2016)

According to the table above, are known to Tonasa cement purchase rate within five years of the tendency of decreasing trend purchase rate of $72.9 \%$ to $62.9 \%$, Bosowa cement shows the percentage of the purchase rate downward trend that is $74.6 \%$ to $63.8 \%$. Indocement also shows the percentage of the purchase rate trend decreased from $61.2 \%$ to $55.6 \%$, and the Holcim cement a downward trend from $55.4 \%$ to $53.8 \%$. Consequently have an impact on satisfaction and loyalty of distributors as customers in the last five years decreased. Visible customer satisfaction showed a downward trend from the year 2011 of $63.4 \%$ through 2015 amounted to 52.9\%, except in 2013 increased by $68.5 \%$. While customer loyalty shows the percentage decline began in 2011 amounted to $60.8 \%$ till 2015 to $55.4 \%$. The occurrence of the downward trend in the level of customer satisfaction and loyalty in this case the distributor, because the application of the marketing mix is not maximized, the quality of service that has not been aligned to the customers and the low level of attention of the consumer behavior that need policy stability of the market. This is the beginning of a phenomenon that needs to be observed and observable, so it becomes important input for the cement company to make a breakthrough marketing policies.

Past studies that analyze customer satisfaction and loyalty, providing evidence that the satisfaction positive and significant impact on customer loyalty (Marshall, 2011); satisfaction and significant negative effect on customer loyalty (Rahim Mosahab, 2010); satisfaction has a positive and significant effect on loyalty (Mohammad, 2015); satisfaction has a positive and significant effect on loyalty (Ishaq et al., 2016); satisfaction has a positive and significant effect on loyalty (Hayan and Samaan, 2015; Basir, 2016). Low satisfaction and customer loyalty perceived by the company, based on the consideration of the field of study of human resources stated that the effect of the marketing mix, quality of service and consumer behavior into problems or obstacles often complained of by the distributor as cement customers. The fact that is often found and perceived by the customer distributor of cement is the problem of the marketing mix, in which the cement company was unable to provide sufficient stock of cement products, cement is often depleted in the market, and this fueled a steady increase in prices could rise at any time in the quarter, rarely do the promotion of innovative, so the brand image 
caused less memorable, and distribution of cement is uneven among distributors and sub-distributors, thereby providing the opportunity to speculation that impact satisfaction and customer satisfaction.

Based on data from the company it is important to apply the marketing mix can be done by using the concept of 4Ps, namely product, price, promotion and place. This concept becomes important to be applied to realize the satisfaction and loyalty of customers to buy the products offered (Kotler, 2008: 211). The practice of the relevance of the marketing mix to customer satisfaction and customer loyalty, shown in a study conducted Marshal (2011) that the marketing mix and no significant negative effect on customer satisfaction and loyalty; marketing mix of positive and significant impact on customer satisfaction and loyalty (Mohammad, 2015); marketing mix of positive and significant impact on loyalty (BK Suthar, 2014).

Services quality provided by the company to customers showed a gap, that the company in providing the service has a low responsiveness to the demands and desires of customers in product purchasing activities. The cement company showed its reliability in providing services major and superior, low caring attitude to provide services quickly and accurately, the lack of physical evidence of the means in making a purchase, so customers usually provide transport to take a cement factory, and the company does not provide a guarantee certainty of service time and guarantee compensation for damage to the product received by customers. This indicates that the quality of services provided by the company were lower results in low customer satisfaction and loyalty, for it required the creation of high quality service so that customers have a high loyalty and for it to be done through the implementation of SERVQUAL to realize a high service quality through responsiveness, reliability, empathy, tangible and Assurances that if implemented properly will give you satisfaction and customer loyalty is high (Parasuraman, 2004: 96).

The effect of service quality on customer satisfaction and customer loyalty demonstrated in studies conducted Marshal (2011) that the service quality have a negative and no significant effect on customer satisfaction and loyalty; services quality has a positive and significant effect on satisfaction and customer loyalty (Jirawat, 2009); services quality has a positive and significant effect on satisfaction and loyalty (Rahim, 2010); there is a weak correlation between the implementation of service quality on satisfaction (Niveen, 2013); service quality has a negative and no significant effect on satisfaction and loyalty (Sabbir, 2012); service quality has a positive and significant effect on customer satisfaction (Krishna, 2010).

Antecedents of other variables in the analysis of customer satisfaction and loyalty, that customer as consumers behave in making purchasing decisions based on environmental needs, in which the company does not consider and pay attention to aspects of the segment, the economic conditions and the environmental situation in the offering of products to customers, the company did not address the purchase decision desired by the customer according to the information and evaluation of the product to be purchased, the company pays little attention to feedback in making a purchase is made the customer and the companies often do not give a response to the reaction product purchases were deemed too high or expensive. The low attention to consumer behavior makes cement customers often feel dissatisfied and disloyal be on the company's products are offered.

Consumer behavior in purchasing the product is an important part in the marketing, Kotler (2008: 95) explains that consumer behavior is important in describing how individual consumers make informed decisions to purchase products. Includes consumer behavior, purchasing decisions, feedback and response, which determines satisfaction and customer loyalty. Empirical evidence shows that consumer behavior has a positive and significant on satisfaction and customer loyalty (Jirawat, 2009); consumer behavior have a negative and no significant effect on satisfaction and loyalty (Sabbir, 2012); consumer behavior has a positive and significant on satisfaction (Krishna, 2010); consumer behavior has a positive and significant on loyalty (BK Suthar, 2014). The difference of this study with previous studies lies in the phenomenon that is disclosed, the fact that the case that variables in analysts showed decreased so that there is a conflict between the theory and the support from previous research.

\subsection{Marketing Mix}

II. LITERATURE REVIEW

The marketing mix used in this study to develop the concept of the marketing mix, marketing the right product that can be done by applying the concept of 4Ps, namely product, price, promotion and place. This concept becomes important to be applied to realize the satisfaction and loyalty of customers to buy the products offered (Kotler, 2008: 211). The empirical evidence shows that the marketing mix have a negative and no significant effect on satisfaction and customer loyalty (Marshall, 2011). Marketing mix has a positive and significant on satisfaction and customer loyalty (Mohammad, 2015). Marketing mix has a positive and significant effect on loyalty (BK Suthar, 2014), thus proposed the following hypotheses:

$\mathrm{H}_{1 \mathrm{a}} \quad$ Marketing mix has a positive and significant effect on customer satisfaction.

$\mathrm{H}_{1 \mathrm{~b}} \quad$ Marketing mix has a positive a positive and significant effect on customer loyalty.

\subsection{Service quality}

Service quality used in the study refers to the dimensions of service quality theory, that there are five dimensions to realize the quality of service. The dimensions are responsiveness, reliability, empathy, tangible and assurance. The fourth dimension of service quality when applied properly will provide increased customer satisfaction and loyalty (Parasuraman, 2004: 96). Empirical evidence shows that the quality of services and no significant negative effect on customer satisfaction and loyalty (Marshall, 2011). Service quality is positive and significant effect on satisfaction and customer loyalty (Jirawat, 2009). Service quality is a positive and significant effect on satisfaction and customer loyalty (Rahim, 2010). There is a weak correlation between the 
implementation of service quality on satisfaction (Niveen, 2013). Service quality is negative and no significant effect on satisfaction and loyalty (Sabbir, 2012). Service quality has a positive and significant on satisfaction (Krishna, 2010), thus proposed the following hypotheses:

$\mathrm{H}_{2 \mathrm{a}} \quad$ Service quality has a positive and significant effect on customer satisfaction.

$\mathrm{H}_{2 b} \quad$ Service quality has a positive and significant effect on customer loyalty.

\subsection{Consumer Behavior}

The measurement of consumer behavioral variables in this study refers to the theoretical model of consumer behavior, that consumer behavior is important in describing how individual consumers make informed decisions to purchase products. The empirical evidence shows that consumer behavior has a positive and significant effect on satisfaction and customer loyalty (Jirawat, 2009). Consumer behavior has a negative and insignificant effect on satisfaction and loyalty (Sabbir, 2012). Consumer behavior has positive and significant effect on satisfaction (Krishna, 2010). Consumer behavior has a positive and significant effect on loyalty (BK Suthar, 2014), thus proposed the following hypotheses:

$\mathrm{H}_{3 \mathrm{a}} \quad$ Consumer behavior has a positive and significant effect on customer satisfaction.

$\mathrm{H}_{3 \mathrm{~b}} \quad$ Consumer behavior has a positive and significant effect on customer loyalty.

\subsection{Customer Satisfaction}

Measurement of customer satisfaction variable refers to the assessment of customer satisfaction, customer satisfaction can be known through the system of complaints and suggestions, satisfaction surveys, activities ghost shopping Contact and old customers (Kotler, 2013: 17). Past studies showing that the satisfaction is directly positive and significant on loyalty (Hayan and Samaan, 2015; Basir, 2016), so the proposed hypothesis is as follows:

$\mathrm{H}_{3} \quad$ Satisfaction has a positive and significant effect on customer loyalty

\subsection{Customer Loyalty}

Customer loyalty is built based on the assumption of loyalty, that assess customer loyal or disloyal views of allegiance to buy back on a regular basis, always recommend the experience to others reference for services received and showed a positive response to the services offered (Norman, 2005: 36). Empirical evidence shows that satisfaction has a positive and significant on customer loyalty (Marshall, 2011). Satisfaction has a negative and significant effect on customer loyalty (Rahim Mosahab, 2010). Satisfaction has a positive and significant effect on loyalty (Ishaq et al., 2016), thus proposed the following hypotheses:

$\mathrm{H}_{4 a} \quad$ Marketing mix has a positive and significant effect on loyalty as a mediated customer satisfaction.

$\mathrm{H}_{4 b} \quad$ Services quality has a positive and significant effect on loyalty as a mediated customer satisfaction.

$\mathrm{H}_{4 \mathrm{c}} \quad$ Consumer behavior has a positive and significant effect on loyalty as a mediated customer satisfaction.

\section{METHOD}

This study is an exploratory study that seeks to find relationships that are relatively new and explanatory research that is done by way of explaining the symptoms caused by an object of research. There are 1,689 customers as the population in this study. Furthermore, the selected sample size determination using the formula Slovin. So the sample in this study was 323 customers. Data analysis techniques used in explaining the phenomenon in this study is a descriptive statistical analysis techniques and analysis of Structural Equation Modeling (SEM).

\section{DISCUSSION AND ANALYSIS}

Based on the method of determining the value in the model, the first model testing variables are grouped into exogenous variables and endogenous variables. Exogenous variables are a variable whose value is determined outside the model. While endogenous variable is a variable whose value is determined by an equation or model-established relationships. Included in the group of exogenous variables is the measurement of the marketing mix, quality of service and consumer behavior, while those classified as an endogenous variable is customer satisfaction and loyalty. The evaluation results indicate the model for the early stages of a model that is still simple, yet indicators showing the relationship of each variable and produced eight criteria of goodness of fit indices were marginally. The results of the evaluation model of early stage shows of the eight criteria of goodness of fit indices with cut-off values generated is still marginal, the modification of advanced model, in order to obtain images the relationship between variables, indicator variables, indicators with indicators and error item of each indicator, Model SEM final stage shows the relationship indicators of each variable and produced eight criteria of goodness of fit indices were seen already met the appropriate criteria for a cut-off value, so that the model can be said to have been in accordance with the criteria of goodness of fit indices to meet test assumptions structural equation modeling. Model testing results are presented in Table 2 following the criteria presented models as well as critical values that have compatibility data. 
Marketing mix: effects of service quality and consumer behavior on loyalty. The mediating role of...

Table 2 Evaluation criteria of Goodness of Fit Indices Overall Model

\begin{tabular}{|c|c|c|c|c|c|}
\hline $\begin{array}{c}\text { Goodness of fit } \\
\text { index }\end{array}$ & Cut-off Value & Early Stage & Annotation & Final Stage & Annotation \\
\hline Chi Square & small & 752.601 & Marginal & 180.699 & Good \\
\hline Probability & $\geq 0.05$ & 0.000 & Marginal & 0.070 & Good \\
\hline CMIN/DF & $\leq 2.00$ & 3.782 & Marginal & 1.173 & 0.022 \\
\hline RMSEA & $\leq 0.08$ & 0.087 & Marginal & 0.957 & Good \\
\hline GFI & $\geq 0.90$ & 0.839 & Marginal & 0.929 & Good \\
\hline AGFI & $\geq 0.90$ & 0.796 & Marginal & 0.977 & Good \\
\hline TLI & $\geq 0.94$ & 0.624 & Marginal & 0.984 & Good \\
\hline CFI & $\geq 0.94$ & 0.676 & Marginal & & \\
\hline
\end{tabular}

Source: Arbuckle (1997); Hair (2006)

The evaluation results indicate the model for the early stages of the eight criteria of goodness of fit indices none meet the criteria for a cut-off value, which be modified according to the instructions of the model modification indices, as previously described. After the modification of the model, then the final stage shows throughout the criterion of goodness of fit indices have met the criteria or according to criteria of the cut-off value, so that the model can be said to have been in accordance with the criteria of goodness of fit indices for analysis. Based on the empirical model proposed in this study can be tested against the hypothesis put forward by testing the path coefficients in structural equation modeling. Table 2 is testing the hypothesis by looking at the $\mathrm{p}$-value, if the $\mathrm{p}$-value $=<0,05$ then the relationship between variables is significant. It also describes the direct effect its means that there are positive directly affect between the variables, the indirect effect means that there are positive indirectly effect between variables and the total effect is the accumulation of direct and indirectly affect.

Based on Table 3, hypothesis testing to see the direct effect, the obtained results show that marketing mix directly has a positive and significant on customer satisfaction, marketing mix has a positive and significant on customer loyalty, and marketing mix has a negative and significant on customer satisfaction and customer loyalty. Table 3 also shows results show that service quality is directly positive and significant on customer satisfaction, service quality has a positive and insignificant effect on customer loyalty, and service quality indirectly have a negative and insignificant effect on customer satisfaction and customer loyalty. From the whole of the model, there are four path provide a direct positive and significant effect, one-path has a negative and significant direct effect. The test results are presented in the following table:

Table 3 Hypothesis testing of direct effect

\begin{tabular}{|c|c|c|c|c|c|c|c|}
\hline \multirow{2}{*}{$\begin{array}{c}\text { Hypothesis } \\
\text { number }\end{array}$} & Exogenous variables & Endogenous variables & \multicolumn{4}{|c|}{ Standardized } \\
\cline { 3 - 8 } & Direct effect & Total effect & \multicolumn{2}{|c|}{ C.R } & p-value & Annotation \\
\hline 1. & Marketing mix $\left(\mathrm{X}_{1}\right)$ & $\begin{array}{c}\text { Customer satisfaction } \\
(\mathrm{Y})\end{array}$ & 0.218 & 0.218 & 2.015 & 0.044 & $(+)$ significant \\
\hline 2. & Service quality $\left(\mathrm{X}_{2}\right)$ & $\begin{array}{c}\text { Customer satisfaction } \\
(\mathrm{Y})\end{array}$ & 0.312 & 0.312 & 2.096 & 0.036 \\
\hline 3. & Consumer behavior $\left(\mathrm{X}_{3}\right)$ & $\begin{array}{c}\text { Customer satisfaction } \\
(\mathrm{Y})\end{array}$ & 0.214 & 0.214 & 1.973 & 0.048 & $(+)$ significant \\
\hline 4. & Marketing mix $\left(\mathrm{X}_{1}\right)$ & Customer loyalty $(\mathrm{Z})$ & 0.908 & 0.908 & 4.173 & 0.000 & $(+)$ significant \\
\hline 5. & Service quality $\left(\mathrm{X}_{2}\right)$ & Customer loyalty $(\mathrm{Z})$ & 0.107 & 0.107 & 0.362 & 0.717 & $(+)$ insignificant \\
\hline 6. & Consumer behavior $\left(\mathrm{X}_{3}\right)$ & Customer loyalty $(\mathrm{Z})$ & 0.063 & 0.063 & 0.363 & 0.717 & $(+)$ insignificant \\
\hline 7. & $\begin{array}{c}\text { Customer satisfaction } \\
(Y)\end{array}$ & Customer loyalty $(\mathrm{Z})$ & 0.449 & 0.449 & 2.775 & 0.006 & $(+)$ significant \\
\hline
\end{tabular}

Source: data processing (2017)

The interpretation of Table 3 for the direct effect can be explained as follows: $\left(\mathrm{H}_{1}\right)$ marketing mix direct positive effect for 0,218 and p-value $=0,044$ significantly on customer satisfaction; $\left(\mathrm{H}_{2}\right)$ service quality directly positive effect for 0,312 and $\mathrm{p}$-value $=0,036$ significantly on customer satisfaction; $\left(\mathrm{H}_{3}\right)$ consumer behavior directly positive effect for 0,214 and p-value $=0,048$ significantly on customer satisfaction; $\left(\mathrm{H}_{4}\right)$ marketing mix directly affect positive and significant at 0.908 and p-value $=0.000$ on customer loyalty; $\left(\mathrm{H}_{5}\right)$ service quality directly positive effect for 0,107 and $\mathrm{p}$-value $=0,717$ are not significant on f customer loyalty; $\left(\mathrm{H}_{6}\right)$ consumer behavior directly positive effect for 0,063 and $\mathrm{p}$-value $=0,717$ are not significant on customer loyalty; and $\left(\mathrm{H}_{7}\right)$ customer satisfaction is directly positive effect for 0,449 and $\mathrm{p}$-value $=0,006$ significantly on customer loyalty. For the results of hypothesis testing indirect effect can be demonstrated in the following table: 
Marketing mix: effects of service quality and consumer behavior on loyalty. The mediating role of...

\begin{tabular}{|c|c|c|c|c|c|c|}
\hline \multirow{2}{*}{$\begin{array}{l}\text { Hypothesis } \\
\text { number }\end{array}$} & \multirow{2}{*}{ Exogenous variables } & \multirow{2}{*}{$\begin{array}{l}\text { Intervening } \\
\text { variables }\end{array}$} & \multirow{2}{*}{ Endogenous variables } & \multicolumn{3}{|c|}{ Standardized } \\
\hline & & & & $\begin{array}{c}\text { Indirect } \\
\text { Effect }\end{array}$ & p-value & Annotation \\
\hline 8. & Marketing mix $\left(\mathrm{X}_{1}\right)$ & $\begin{array}{c}\text { Customer } \\
\text { satisfaction }(\mathrm{Y})\end{array}$ & Customer loyalty (Z) & $-0,098$ & 0,000 & (-) significant \\
\hline 9. & Service quality $\left(X_{2}\right)$ & $\begin{array}{c}\text { Customer } \\
\text { satisfaction }(\mathrm{Y})\end{array}$ & Customer loyalty (Z) & $-0,140$ & 0,717 & (-) insignificant \\
\hline 10. & $\begin{array}{c}\text { Consumer behavior } \\
\left(\mathrm{X}_{3}\right)\end{array}$ & $\begin{array}{c}\text { Customer } \\
\text { satisfaction (Y) }\end{array}$ & Customer loyalty (Z) & $-0,096$ & 0,717 & (-) insignificant \\
\hline
\end{tabular}

Source: data processing (2017)

From the whole of the model there is one lane indirect effect negative and significant, two-path direct positive influence and insignificant, as well as two path indirect effect is negative and significant. The interpretation of Table 4 for the indirect effect can be explained as follows: $\left(\mathrm{H}_{8}\right)$ marketing mix indirectly through customer satisfaction the negative and significant effect on at -0098 and p-value $=0,000$ on customer loyalty; $\left(\mathrm{H}_{9}\right)$ service quality indirectly through of customer satisfaction the negative and insignificant effect at 0140 and $\mathrm{p}$-value $=0,717$ on customer loyalty; and $\left(\mathrm{H}_{10}\right)$ consumer behavior indirectly through the negative effect of customer satisfaction at $-0,096$ and $p$-value $=0,717$ were not significant on customer loyalty.

\section{CONCLUSION}

Based on the research that has been described, it is concluded: (1) marketing mix has a positive and significant on customer satisfaction; (2) service quality has a positive significant effect on customer satisfaction; (3) consumer behavior has a positive and significant effect on customer satisfaction; (4) marketing mix has a positive and significant effect on customer loyalty; (5) service quality have a positive and insignificant effect on customer loyalty; (6) consumer behavior has a positive and insignificant effect on customer loyalty; (7) Customer satisfaction has a positive and significant effect on customer loyalty; (8) marketing mix indirectly negative and significant effect on loyalty through customer satisfaction; (9) service quality indirectly negative and insignificant effect on loyalty through customer satisfaction cement; and (10) consumer behavior indirectly negative and insignificant effect on loyalty through customer satisfaction.

\section{REFERENCES}

[1] Andriyani, Annisa, (1999). Principles of Marketing, Eighth Edition, Translation by Damos Sihombing, Erlangga. Jakarta.

[2] Assauri, Sofyan, (2001). Marketing Production and Operations Management. Jakarta: Issuing Faculty of Economics Indonesian University.

[3] Bill, Jose Gennet, (2009). Function in Marketing Strategy: An Review http: //www.marketingstrategy\&function.com.id access April 9, 2013.

[4] Chan, Hui \& Lee, Mich, (2010). Marketing performance Management. $2^{\text {nd }}$ Edition, Mas Hougton Mifflin Company, Boston.

[5] Engel, JF et al. (2010). Customer Behavior, 6th ed. Chicago:the Dryden Press Chicago.

[6] Gasperz, (2008). Marketing. Third Edition, Richard D. Irwin, USA.

[7] Kartajaya, (2003). Marketing Management and Marketing Services. CV. Alfabeta. Bandung.

[8] Kotler, Philip \& Keller, KL (2010). Principles of Marketing. $10^{\text {th }}$ ed. Prentice Hall New Jersey.

[9] Kotler, Philip \& Gary Armstrong, (2010). Principles of Marketing, 6th ed. Englewood Cliffs, N.J: Prentice-Hall International, Inc

[10] Kotler, Philip, (2008). Marketing Management and Consumer Behavior. The Millennium Edition. Prentice Hall, Inc. New Jersey.

[11] Kotler, Philip, (2008). Marketing Management, Analysis, Planning, Implementation andControl.Issue 9 PT. Prenhallindo,

Jakarta.

[12] Kotler, Philip, (2008). Marketing Management:Analysis, Planning, Implementation, and Control, $9^{\text {th }}$ ed. Englewood Cliffs, N.J: Prentice-Hall International, Inc.

[13] Margaretha, (2009). Quality of Service: Theory and Applications. Mandar Maju, Jakarta.

[14] Nelson, William, 2006. Marketing and Strategy in Marketing. McMillan, Canada.

[15] Nitisemito, Alex. S. (2010). Marketing. Ghalia Indonesia, Jakarta.

[16] Parasuraman, A. Valerie, (2001). Delivering Quality Service. The Free Press, New York. (Translated by Sutanto).

[17] Tjiptono, Fandy, (2000). Principles of Marketing, Eighth Edition, Translation by Damos Sihombing, Erlangga, Jakarta.

[18] Tjiptono, Fandy, (2004). Marketing Services, Revised Edition, Erlangga, Jakarta.

[19] Tunggal Amin Praja, (2010). Assessment System in Improving Marketing Products and Services. Harvarindo. Jakarta.

[20] Walker, Domascus, (2008). Competitive and Performance Marketing. Prentice Hall Cliffs, New Jersey.

[21] Zeithaml, Valarie, A \& Bitner, A., (2001). The Behavioral Consequencies Of Service Quality, Journal of Marketing, 60 (2): $31-$

46.

[22] Zeithaml, Valarie A., (2001). Service Quality, Profitability, And The Economic Worth Of Costumers: What We Know and What We Need To Learn. Journal Of The Academy Of Marketing Sciences 28 (1): 67-85. 